Удк 616-071+616.37-002

DOI 10.11603/2414-4533.2020.1.10751

СІ. М. ШЕВЧУК, В. І. ПИЛИПЧУК, В. М. ГАЛЮК

Івано-Франківський національний медичний університет

\title{
Сучасні аспекти хірургічного лікування ускладнених форм хронічного панкреатиту
}

\begin{abstract}
Мета роботи: покращення результатів хірургічного лікування хворих на ускладнені форми ХП з порушенням функції суміжних органів.

Матеріали і методи. Проведено аналіз результатів обстеження та лікування 182 хворих на хронічний панкреатит (ХП).

Результати досліджень та їх обговорення. У 43,9 \% хворих мали місце чітко виражені симптоми пошкодження сусідніх органів, спричинені хронічним панкреатитом. Найчастіше зустрічалась біліарна гіпертензія (БГ). У 99 (54,4%) хворих виконано операції резекційного типу. Операції дренуючого типу проведено у 77 (42,3 \%) хворих. У 6 (3,3 \%) хворих із тяжкою супутньою патологією виконані симптоматичні операції. У хворих, у яких виявлено порушення функції суміжних органів, операції резекційного типу були застосовані у 76,3 \% випадків. При вивченні віддалених результатів кращими виявились показники якості життя у хворих, які перенесли резекційні операції на ПЗ. Проведені об’єктивні дослідження, лабораторні та дані УзД вказували на відсутність у пацієнтів ознак порушень функції суміжних органів у віддалені терміни після операції.

Хронічний панкреатит є тяжким захворюванням, при якому у 15,1 \% наявні ознаки екдокринної недостатності П3, у 79,2 \% - екзокринної недостатності, а у 43,9 \% - симптоми порушення функції суміжних органів. Відсутність чітко сформульованих показів до оперативного втручання хронічного панкреатиту спричиняє його тривале та малоефективне консервативне лікування, часто призводить до запізнілої госпіталізації в хірургічний стаціонар та в кінцевому результаті - до не завжди позитивних результатів операції. Основними методами хірургічного лікування хворих на ХП вважаємо резекційні, які ми використали у 54,3 \% випадків, проте у пацієнтів з порушенням функцій суміжних органів питама вага таких оперативних втручань зростає до $76,3 \%$.
\end{abstract}

Ключові слова: хронічний панкреатит; хірургічне лікування; віддалені наслідки.

Постановка проблеми і аналіз останніх досліджень та публікацій. На сьогодні спостерігається невпинне зростання захворюваності на хронічний панкреатит (ХП), у світі вона становить 3,1-8 випадків, в країнах Європи - 4-8 випадків, поширеність - 25 випадків на 100 тис. населення; в Україні рівень захворюваності патологією підшлункової залози (ПЗ) в 2012 році становив 226 випадків на 100 тис. населення, поширеність - 2471 на 100 тис. населення [1]. Щорічно тільки в Україні виявляють на 5000-6000 хворих з ураженням ПЗ більше, ніж в попередні роки [2]. За останні тридцять років спостерігається більш ніж дворазове зростання кількості хворих на ХП [3, 4].

Більшість дослідників розглядає ХП як прогресуюче захворювання 3 загостреннями хронічного запалення, які повторюються, розвитком склерозу і фіброзу, які приводять до заміщення секреторної тканини залози сполучною тканиною і зниження зовнішньосекреторної функції ПЗ [5].

Загальна смертність від ХП у пацієнтів з алкогольним панкреатитом, які хворіють більше 20 років складає від 28,8 до 35,0 \% [6]. Первинна інвалідизація хворих на ХП досягає $15 \%$, при цьому в цілому захворювання ПЗ в 10,9 \% випадків є причиною інвалідизації хворих із патологією органів травлення [7].
Мета роботи: покращення результатів хірургічного лікування хворих на ускладнені форми ХП із порушенням функції суміжних органів.

Матеріали і методи. Проведено аналіз результатів обстеження та хірургічного лікування 182 хворих на ХП, які перебували у хірургічному відділенні Івано-Франківської обласної клінічної лікарні у період 2012-2018 рр. Кількість чоловіків значно переважала над кількістю жінок: жінок було 10 (5,5 \%), чоловіків - 172 (94,5 \%), віком від 21 до 63 років, середній вік - $(45,8 \pm 0,8)$ року.

3 метою максимально точного визначення характеру патологічного процесу, наявності та вираженості ускладнень, ступеня компенсації функцій ПЗ, ступеня та вираженості змін печінки та жовчних протоків хворим проводили комплексне всебічне обстеження до операції, в ранньому післяопераційному періоді (до виписування з стаціонару) та у віддалені строки після операції (від 6 міс. до 7 років).

До операції пацієнтам проведене обстеження в такому обсязі: клінічні та лабораторні дослідження, ультразвукове дослідження (УЗД), езофагогастродуоденофіброскопія (ЕФГДС) та/або ендоскопічна ретроградна холангіопанкреатографія (ЕРХПГ), комп’ютерна томографія (КТ), магніт- 
но-резонансна холангіопанкреатографія (МРХПГ), додаткові дослідження з приводу супутніх захворювань та ускладнень. Гістологічне дослідження проведено всім хворим, яким виконували відкриті оперативні втручання, дане дослідження вважали основним доказом діагнозу ХП та використовували для остаточного виключення наявності онкопроцесу в ПЗ.

Для статистичної обробки отриманих результатів дослідження сформовано базу даних на основi Microsoft Excel, де матеріали групувались за контингентами вивчення, статистичні розрахунки проводилися за допомогою вбудованих ліцензійних пакетів аналізу даних та описової статистики в програмах Microsoft Excel 2007 та Statistica 6.0. Статистична обробка категорійних (якісних) даних проводилась шляхом розрахунку частоти поширення ознак на 100 обстежених (\%), а перевірка достовірності різниці даних в групах порівняння здійснювалась шляхом розрахунку критерію відповідності $\chi^{2}$.

Результати досліджень та їх обговорення. Клінічне обстеження хворих на ХП вказувало на наявність тяжких порушень з боку різних органів та систем. Тривалість клінічних проявів ХП хворих коливалась від 6 міс. до 10 років, в середньому $(5,2 \pm 1,2)$ року.

Порушення функції сусідніх органів мало місце у 80 (43,9 \%) хворих (табл. 1).

Симптоми хронічної дуоденальної непрохідності були чітко виражені у 11 хворих (6,0 \%). Венозна гіпертензія судин гепатопанкреатичної зони була діагностована у 5 (2,7 \%) хворих; ще у 64 (35,2 \%) пацієнтів була виявлена БГ, пов’язана 3 патологічним процесом в головці ПЗ. У 3 хворих ознаки біліарної гіпертензії та хронічної дуоденальної непрохідності були одночасно. Отже, 80 хворих (43,9 \%) мали чітко виражені симптоми пошкодження сусідніх органів, спричинені хронічним панкреатитом.
Жовтяницю діагностовано у 45 (24,7 \%) хворих. У 12 (6,5 \%) хворих жовтяниця була неодноразово, у 33 (18,1 \%) хворих виникла вперше. У 20 (10,1 \%) хворих БГ перебігала субклінічно.

Під час лабораторного обстеження гіпербілірубінемія визначалась у 49 (26,9 \%) хворих, у 15 (8,2 \%) пацієнтів БГ перебігала без гіпербілірубінемії.

Показання до оперативного лікування ХП визначені неостаточно. Як правило, питання про оперативне втручання виникає при наявності стійкого больового синдрому, що не піддається консервативній терапії та при вираженій недостатності зовнішьосекреторної функції ПЗ. Оперативне втручання показане при наявності клінічних проявів ХП та морфологічних змінах ПЗ, коли консервативна терапія неефективна та існує загроза виникнення ускладнень ХП.

Операції резекційного типу виконано у 99 (54,4 \%) хворих. Показаннями до резекційних оперативних втручань вважали наявність вираженого хронічного запального процесу в ділянці головки ПЗ (ПДР, операція Бегера, Фрея, Бернська методика) чи в ділянці хвоста залози (дистальна резекція).

У виборі методу хірургічного втручання керувались тим, що операції резекційного типу, а також їх сучасні модифікації дозволяють ліквідувати БГ, панкреатичну протокову гіпертензію, в частині випадків - компресію порто-селезінково-мезентеріального конфлюенсу з нормалізацією портального кровообігу (це менше стосується операції Фрея), хронічний абдомінальний біль.

Негативною стороною операцій резекційного типу є зниження функціональних резервів ПЗ (ек3о- та ендокринної функції). За результатами дослідження, на момент операції виражені прояви зовнішньосекреторної недостатності були у 79,2 \% хворих, а внутрішньосекреторної - в 15,1 \% хворих. Під час вибору методу операції враховували, що у хворих на ускладнені форми ХП частина па-

Таблиця 1. Порушення функції суміжних органів у хворих на хронічний панкреатит

\begin{tabular}{||l|c|c||}
\hline \multicolumn{1}{|c|}{ Порушення функції органів } & Кількість хворих $(\mathrm{n}=182)$ & Відсоток, \% \\
\hline БГ & 64 & 35,2 \\
\hline ХДН & 11 & 6,0 \\
\hline ВГ & 5 & 2,7 \\
\hline БГ + ХДН & 3 & 1,6 \\
\hline БГ + ХДН + ВГ & 2 & 1,1 \\
\hline Разом & 80 & 43,9 \\
\hline
\end{tabular}


ренхіми ПЗ вже зазнала фіброзно-дегенеративних змін.

При виражених фіброзно-дегенеративних змінах в головці П3, які супроводжувались больовим синдромом, явищами БГ, ХДН чи ВГ, методом вибору були дуоденумзберігальні резекції ПЗ (операції Фрея, Бернська операція) - 65 (41,7 \%) хворих та ПДР.

Бернську модифікацію операції Бегера виконано у 5 (2,9 \%) хворих. Ї̈̈ виконували при ХП $з$ переважним ураженням головки ПЗ та мало зміненими протоками тіла та хвоста залози. При наявності БГ останню вдалось усунути шляхом звільнення інтрапанкреатичної частини ЗЖП від фіброзно-дегенеративних тканин, тому операцій на жовчовивідних протоках не застосовували.

Виконання операції Фрея з широким перидуктальним висіченням фіброзно-дегенеративних тканин головки ПЗ сприяло усуненню БГ. У 3 хворих біліарну декомпресію досягнуто висіченням язичка ПЗ. У 21 (33,3 \%) хворих операцію Фрея доповнено накладанням ГЕА через утримання БГ після виконання резекційного етапу операції. Ще у 3 хворих накладено біліопанкреатичний анастомоз.

3 метою біліарної декомпресії розроблено та у 4 хворих застосовано метод оперативного втручання (пат. України на корисну модель № 93960) [23].

При обгрунтованій підозрі на онкопроцес в ділянці головки залози методом вибору була стандартна ПДР - 5 (2,7 \%) хворих. При наявності ізольованого фіброзного чи фіброзно-дегенеративного процесу хвоста ПЗ або при підозрі на пухлинний процес у 12 (6,6 \%) хворих проведено дистальну резекцію ПЗ. У виборі методу хірургічного втручання керувались тим, операції резекційного типу, а також їх сучасні модифікації дозволяють ліквідувати ряд ускладнень ХП, а саме: панкреатичну протокову гіпертензію, в частині випадків - БГ та компресію порто-селезінково-мезентеріального конфлюенсу з нормалізацією портального кровообігу (це менше стосується операції Фрея), хронічний абдомінальний біль.

Серед 80 хворих, у яких було виявлено порушення функції суміжних органів, резекційні методи були застововані у 76,3 \%.

Операції дренуючого типу проведено у 77 (42,3 \%) хворих. Зокрема, при ізольованому вірсунголітіазі, розширенні ГПП без стенозу і оклюзї протоків та без значної фіброзної дегенерації головки ПЗ, при ХП з атрофією головки ПЗ та вірсунгоектазією методом вибору оперативного втручання була ППЕС - 37 (20,3 \%) хворих. У 3 (1,6 \%) хворих проведено ендоскопічне стентування ГПП, у 1 з них одночасно виконано літоекстракцію з ГПП. Проте у 2 хворих після цього втручання через прогресування фіброзно-дегенеративних змін в головці ПЗ пізніше виникла потреба у виконанні резекційних втручань на головці ПЗ. При кістах ПЗ проведено такі операції: відкриту цистоентеростомію - 21 (11,5 \%) хворому, ще у 2 (1,1 \%) вдалось виконати цистоентеростомію лапароскопічно, ендоскопічну дуоденоцистостомію - 5 (2,7 \%) хворим.

У 6 (3,3 \%) хворих 3 тяжкою супутньою патологією виконані симптоматичні операції: накладання обхідних біліодигестивних анастомозів (при біліарній гіпертензії та жовтяниці) - 3 хворі, ЕРХПГ з ендобіліарним стентуванням (при механічній жовтяниці) - 3 хворі.

Результати хірургічного лікування вивчено у 43 (23,6 \%) хворих в терміни від 6 міс. до 3 років. За результатами анкетування всі хворі оцінили свій фізичний та психоемоційний стан як добрий та задовільний. Кращими виявились показники якості життя у хворих, які перенесли резекційні операції на ПЗ. Проведені об’єктивні дослідження, лабораторні та дані УЗД вказували на відсутність у пацієнтів ознак порушень функції суміжних органів у віддалені терміни після операції.

Висновки. 1. Хронічний панкреатит є тяжким захворюванням, при якому у 15,1 \% наявні ознаки екдокринної недостатності ПЗ, у 79,2 \% - екзокринної недостатності, а у 43,9 \% - симптоми порушення функції суміжних органів.

2. Відсутність чітко сформульованих показань до оперативного втручання хронічного панкреатиту спричиняє його тривале та малоефективне консервативне лікування, часто призводить до запізнілої госпіталізації в хірургічний стаціонар та в кінцевому результаті - до не завжди позитивних результатів операції.

3. Основними методами хірургічного лікування хворих на ХП вважаємо резекційні, які ми використали у 54,3 \% випадків, проте у пацієнтів 3 порушенням функцій суміжних органів питама вага таких ореративних втручань зростає до 76,3 \%.

Перспективи подальших досліджень. Вважаємо за необхідне розробку алгоритму щодо раннього виявлення пацієнтів із хронічним панкреатитом з метою попередження розвитку у них ускладнених форм. 


\section{СПИСОК ЛІТЕРАТУРИ}

1. Просоленко К. А. Курация пациентов с хроническим панкреатитом согласно последним украинским стандартам / К. А. Просоленко // Вестник клуба панкреатологов. - 2016. № 2 (31). - C. 5-11.

2. Хірургічне лікування хронічного панкреатиту / В. I. Русин, С. С. Філіп, О. О. Болдіжар [та ін.] // Харківська хірургічна школа. - 2014. - № 2(65). - С. 29-34.

3. Криворучко И. А. Хирургическое лечение хронического панкреатита с учетом классификации М. Buchler и соавторов (2009) / И. А. Криворучко, В. В. Бойко, Н. Н. Гончарова // Сучасні медичні технології. - 2011. - № 3-4.- С. 195-198. 4. Склад жовчі у хворих на хронічний панкреатит / О. І. Дронов, І. О. Ковальська, Ю. П. Швець [та ін.] // Клін. хірургія. - 2013. - № 5.- С. 14-17.

\section{REFERENCES}

1. Prosolenko, K.A. (2016). Kuratsiya patsiyentov s khronicheskim pankreatitom soglasno poslednim ukrainskim standartam [Curation of patients with chronic pancreatitis according to modern Ukrainian standart]. Vestnik kluba pankreatologov - Journal of the Pancreatology Club, 2 (31), 5-11 [in Russian].

2. Rusyn, V.I., Filip, S.S., Boldizhar, O.O., \& Rumiantsev, K. Ye. (2014). Khirurhichne likuvannia khronichnoho pankreatytu [Surgical treatment of chronic pancreatitis]. Kharkivska khirurhichna shkola - Kharkiv School of Surgery, 2 (65), 29-35 [in Ukrainian].

3. Krivoruchko, I.A., Boyko, V. V., \& Goncharova, N.N. (2011) Khirurgicheskoe lechenie khronicheskogo pankreatita s uchetom klassifikatsii M. Buchler i soavtorov (2009) [Surgical treatment os chronic pancreatitis according to classification M Buchler 2009]. Suchasni medychni tekhnolohii - Modern Medical Technology, 3-4, 195-198 [in Russian].

4. Dronov, O.I., Kovalska, Yu.P., Shvets, S.P., \& Veselskyi, S.P.
5. Sebastiano di P. Pathophysiology of chronic Bmage / P. di Sebastiano, F. F. di Mola // Acute anc Chronic Pancreatitis: New concepts and evidence-based approaches / ed. By P. A. Testoni, A. Mariani, P. G. Arcidiacono. - Turin: Edizioni Minerva Medica, 2013. - P. 63-69

6. Vantini I. Chronic pancreatitis: clinical course, pancreatic insufficiency and metabolic consequences / I. Vantini, A. Amodio, A. Gabbrielli // Acute and Chronic Pancreatitis: New Concepts and Evidence-Based Approachesю - ed. by. P. A. Testoni, A. Mariani, P. G. Arcidiacono. - Turin : Edizioni Minerva Medica, 2013. - P. 71-82

7. Минушкин О. Н. Хронический панкреатит: эпидемиология, этиология, классификация / О. Н. Минушкин // Фарматека. - 2007. - № 2. - С. 53-56.

(2009). Sklad zhovchi u khvorykh na khronichnyi pankreatyt [The composition of bile in patient with chronic pancreatitis]. Klinichna khirurhiia - Clinical Surgery, 5, 14-17 [in Ukrainian].

5. Sebastiano, P. di., \& Mola, F. F. di (2013). Pathophysiology of chronic damage acute anc chronic pancreatitis: New concepts and evidence-based approaches. Testoni, P.A., Mariani, A., Arcidiacono, P.G. (Eds.). Turin: Edizioni Minerva Medica.

6. Vantini, I., Amodio, A., Gabbrielli, A., Cristofori, C., Frulloni, L., \& Benini, L. (2013). Chronic pancreatitis: clinical course, pancreatic insufficiency and metabolic consequences Acute and Chronic Pancreatitis: New Concepts and Evidence-Based Approaches. Testoni, P.A., Mariani, A., \& Arcidiacono, P.G. (Eds.). Turin: Edizioni Minerva Medica.

7. Minushkin, O.N. (2007). Khronicheskiy pankreatit: epidemiologiya, etiologiya, klassifikatsiya [Chronic pancreatitis: epidemiology, etiology, classification]. Farmateka - Farmateca, 2, 5356 [in Russian].

\section{MODERN ASPECTS OF SURGICAL TREATMENT OF COMPLICATED FORMS OF THE CHRONIC PANCREATITIS}

The aim of the work: improvement of the results of surgical treatment of patients with complicated forms of CP with violation of the function of adjacent organs.

Materials and Methods. The analysis of the results of the examination and treatment of 182 patients with CP was performed. Results and Discussion. 43.9 \% of patients had clear symptoms of damage to neighboring organs caused by chronic pancreatitis. Most often there was biliary hypertension. In 99 (54.4\%) patients resection-type operations were performed. The operations of the drainage type were performed in 77 (42.3\%) patients. In 6 (3.3\%) patients with severe concomitant pathology there were performed symptomatic operations. In patients with the disorders of the function of adjacent organs, resection-type operations were used in $76.3 \%$ of cases. In the study of long-term results, the quality of life indicators in patients who undergone resection operations on pancreas were the best ones. The performed objective studies, laboratory and ultrasound data indicated that patients had no signs of abnormalities in adjacent organs in the long-term period after surgery.

Chronic pancreatitis is a serious illness in which $15.1 \%$ have signs of endocrine insufficiency of the pancreas, $79.2 \%$ have exocrine insufficiency, and $43.9 \%$ have symptoms of abnormalities in the function of adjacent organs. The absence of well-defined indications for surgical intervention of chronic pancreatitis leads to its long and ineffective conservative treatment, often leads to delayed hospita- 


\section{З ДОСВІДУ РОБОТИ}

lization in the surgical hospital and, ultimately - to not always positive results of the operation. The main methods of surgical treatment of patients with $\mathrm{CP}$ are resection, which we used in $54.3 \%$ of cases, but in patients with a violation of the functions of adjacent organs, the specific weight of such irregular interferences increases to $76.3 \%$.

Key words: chronic pancreatitis; surgical treatment; long-term consequences.

И. М. ШЕВЧУК, В. И. ПЫЛЫПЧУК, В. М. ГАЛЮК

Ивано-Франковский национальный медицинский университет

\section{АСПЕКТЫ ХИРУРГИЧЕСКОГО ЛЕЧЕНИЯ ОС.ЛЖНЕННЫХ ФОРМ ХРОНИЧЕСКОГО ПАНКРЕАТИТА}

Цель работы: улучшить результаты хирургического лечения больных с осложненными формами хронического панкреатита с нарушением функции смежных органов.

Материалы и методы. Проведен анализ результатов обследования и лечения 182 больных хроническим панкреатитом (ХП). Результаты исследований и их обсуждение. В 43,9 \% больных имели место четко выраженные симптомы повреждения смежных органов, вызванные хроническим панкреатитом. Чаще всего встречалась билиарная гипертензия (БГ). В 99 (54,4 \%) больных выполнено операции резекционного типа. Операции дренирующего типа проведено в 77 (42,3 \%) больных. У 6 (3,3 \%) больных с тяжелой сопутствующей патологией выполнены симптоматические операции. У больных, в которых выявлены нарушения функции смежных органов, операции резекционного типа были применены в 76,3 \% случаев. При изучении отдаленных результатов лучше оказались показатели качества жизни у больных, перенесших резекционные операции на ПЖ. Проведенные объективные исследования, лабораторные и данные УзИ указывали на отсутствие у пациентов признаков нарушений функции смежных органов в отдаленные сроки после операции.

Хронический панкреатит является тяжелым заболеванием, при котором в 15,1 \% имеются признаки экдокринной недостаточности ПЖ, в 79,2 \% - экзокринной недостаточности, а в 43,9 \% - симптомы нарушения функции смежных органов. Отсутствие четко сформулированных показаний к оперативному вмешательству хронического панкреатита приводит к его длительному и малоэффективному консервативному лечению, часто приводит к запоздалой госпитализации в хирургический стационар и в конечном итоге - к не всегда положительным результатам операции. Основными методами хирургического лечения больных ХП считаем резекционные, которые мы использовали в 54,3 \% случаев, однако у пациентов с нарушением функции смежных органов удельный вес таких оперативних вмешательств возрастает до 76,3%.

Ключевые слова: хронический панкреатит; хирургическое лечение; отдаленные последствия. 